\title{
The Impact of Resveratrol on Oxidative Stress Induced by Methotrexate in Rat lleum Tissue: Evaluation of Biochemical and Histopathological Features and Analysis of Gene Expression
}

\author{
Adalet Ozcicek $^{a}$ Nihal Cetin ${ }^{b}$ Ferda Keskin Cimen ${ }^{c}$ Levent Tumkaya ${ }^{f}$ \\ Ismail Malkoc ${ }^{d}$ Mine Gulaboglue Oguzhan Yaralig Bahadir Suleyman ${ }^{b}$
}

Departments of ${ }^{\mathrm{a}}$ Internal Medicine and ${ }^{\mathrm{b}}$ Pharmacology, Faculty of Medicine, Erzincan University, and ${ }^{\mathrm{c}}$ Department of Pathology, Mengucek Gazi Training and Research Hospital, Erzincan, Departments of ${ }^{\mathrm{d}}$ Anatomy, Faculty of Medicine and ${ }^{~}$ Biochemistry, Faculty of Pharmacy, Ataturk University, Erzurum, ${ }^{f}$ Department of Histology and Embryology, Faculty of Medicine, Recep Tayyip Erdogan University, Rize, and ${ }^{9}$ Department of Medical Genetics, Goztepe Training and Research Hospital, Istanbul Medeniyet University, Istanbul, Turkey

\section{Key Words}

Gene expression · Oxidative stress · Resveratrol · lleum tissue $\cdot$ Rat

\begin{abstract}
Objective: The aim of this study was to assess the impact of resveratrol (RST) on oxidative stress induced by methotrexate in rat ileum tissue. Materials and Methods: Twenty-four rats were divided into 4 groups with 6 in each group. Each rat was orally administered the following every day for 30 days: group 1 (MTXG), methotrexate (MTX; $5 \mathrm{mg} / \mathrm{kg}$ ); group 2 (RMTXG), MTX (5 mg/kg) plus RST ( $25 \mathrm{mg} / \mathrm{kg} /$ day); group 3 (RSTG), RST alone ( $25 \mathrm{mg} / \mathrm{kg} /$ day), and group 4 (controls), distilled water. After the rats had been sacrified, the ilea were removed for the assessment of malondialdehyde (MDA), total glutathione (tGSH) and glutathione peroxidase (GSH-Px). Gene expression analyses for interleukin-1 $\beta$ (IL-1 $\beta$ ), tumor necrosis factor-a (TNF- $\alpha$ ) and myeloperoxidase (MPO) were also performed. Hematoxylin and eosin-stained paraffinembedded sections of the ileum were analyzed under a light microscope and the findings were recorded. Statistical analyses of the data were performed using one-way ANOVA. $\boldsymbol{R e}$ -
\end{abstract}

\begin{tabular}{ll}
\hline KARGER & $\begin{array}{l}\text { ( } 2015 \text { S. Karger AG, Basel } \\
1011-7571 / 15 / 0252-0181 \$ 39.50 / 0\end{array}$ \\
E-Mail karger@karger.com & $\begin{array}{l}\text { This is an Open Access article licensed under the terms of the } \\
\text { www.karger.com/mpp }\end{array}$ \\
$\begin{array}{l}\text { Creative Commons Attribution-NonCommercial 3.0 Un- } \\
\text { ported license (CC BY-NC) (www.karger.com/OA-license), } \\
\text { applicable to the online version of the article only. Distribu- } \\
\text { tion permitted for non-commercial purposes only. }\end{array}$
\end{tabular}

sults: The administration of MTX in group 1 yielded a higher level of MDA $(8.33 \pm 2.5 \mu \mathrm{mol} / \mathrm{g}$ protein, $\mathrm{p}<0.001)$ and lower levels of tGSH $(0.97 \pm 0.29 \mathrm{nmol} / \mathrm{g}$ protein) and GSH-Px $(5.22 \pm 0.35 \mathrm{U} / \mathrm{g}$ protein, $\mathrm{p}<0.001)$ compared to the other groups. MTX also increased IL-1 $\beta(40.33 \pm 5.43$ gene expression levels), TNF-a (6.08 \pm 0.59$)$ and MPO gene expression $(9 \pm 1.41)$ in group 1 compared to the controls $(11.33 \pm 2.07$, $2.15 \pm 0.33$ and $3.43 \pm 0.48$, respectively, $p<0.001)$. The impact of RST on IL-1 $\beta$, TNF- $\alpha$ and MPO gene expression induced by MTX was observed as a reversal of these findings $(p<0.05)$. Severe inflammation, damage to the villus epithelium and crypt necrosis was observed histopathologically in the MTXG group, whereas only mild inflammation was seen in the RMTXG group. Conclusion: In this study, ileal damage caused by MTX was inhibited by RST. $\quad$ @ $2015 \mathrm{~S}$. Karger AG, Basel

\section{Introduction}

Methotrexate (MTX), a folic acid analogue, inhibits the dihydrofolate reductase enzyme and is used as a chemotherapeutic agent [1]. It is also among the first-line 
drugs used to treat inflammatory diseases such as juvenile idiopathic arthritis, psoriatic arthritis, polymyositis, systemic lupus erythematosus and ankylosing spondylitis [2]. However, there are side effects of MTX, particularly small intestinal toxicity, which is one of its greatest drawbacks. Wang et al. [3] reported mucositis in the small intestine caused by MTX. Theoretically, the addition of folic acid to treatment can reduce the toxic effects of MTX, but so far no consensus has been reached on this. In contrast, it was suggested that the addition of folic acid to the therapeutic MTX dose reduces its efficacy [4]. The relevant studies suggest that oxidative stress plays a key role in the pathogenesis of MTX toxicity because it causes damage by inhibiting enzymatic and nonenzymatic antioxidants, thereby increasing oxidants in tissues [5]. The damage induced by MTX is described to start with the formation of reactive oxygen species, to continue with the activation of transcription factors and release of proinflammatory cytokines such as tumor necrosis factor- $\alpha$ (TNF- $\alpha$ ) and interleukin-1 $\beta$ (IL-1 $\beta$ ), leading to mucosal damage and cell death [6]. An increased production of TNF- $\alpha$, IL-1 $\beta$ and myeloperoxidase (MPO) has been demonstrated in small intestinal damage induced by MTX $[7,8]$. Oxidative stress has been shown to play a major role in intestinal toxicity due to MTX, and this toxic effect may be prevented by antioxidant therapy [9].

Resveratrol (RST; 3,4,5-trihydroxy-trans-stilbene, 5-[(1E)-2-(4-hydroxyphenyl)ethenyl]-1,3-benzenediol) is a polyphenolic compound [10] with reported antioxidant and anti-inflammatory effects. It prevents cell death through increased IL- $1 \beta$ in chondrocytes and antagonizes the effect of TNF- $\alpha[11,12]$. Therefore, the objective of this study was to assess the impact of RST on oxidative stress induced by MTX in rat ileum tissue by evaluating biochemical and histopathological changes and analyzing gene expression.

\section{Materials and Methods}

\section{Animals}

All animals used in this experiment were obtained from the Center of Medical Experiments and Research, Recep Tayyip Erdogan University, Rize, Turkey. A total of 24 male albino Wistar rats, each weighing 230-240 g, were randomly chosen and divided into 4 groups, with 6 rats in each group. The rats were kept and fed in the pharmacology laboratory at a normal room temperature $\left(22^{\circ} \mathrm{C}\right)$. The animal experiments were performed in accordance with the National Guidelines for the Use and Care of Laboratory Animals and were approved by the Animal Ethics Committee of Recep Tayyip Erdogan University (Ethics Committee No.: 2015/9, dated February 20, 2015).

\section{Chemical Substances}

The chemical substances used in the experiments were RST (Sigma-Aldrich, St. Louis, Mo., USA), thiopental sodium (IE Ulagay, Istanbul, Turkey) and MTX (Med-İlaç, Istanbul, Turkey).

\section{Test Groups}

The study was divided into 4 groups, each including 6 rats. The rats were orally administered the following each day for 30 days: group 1 (MTXG), MTX (5 mg/kg), which caused gastric damage [5]; group 2 (RMTXG), RST ( $25 \mathrm{mg} / \mathrm{kg}$ ) followed $1 \mathrm{~h}$ later by MTX $(5 \mathrm{mg} / \mathrm{kg}) ;$ group 3 (RSTG), RST $(25 \mathrm{mg} / \mathrm{kg}$ ), and group 4 (controls), distilled water only. At the end of the 30th day the rats were sacrificed under high-dose thiopental sodium anesthesia, and their ilea were taken out and assessed for malondialdehyde (MDA), total glutathione (tGSH) and glutathione peroxidase (GSH-Px) levels. Gene expression of IL-1 $\beta$, TNF- $\alpha$ and MPO, as well as histopathological features, were also assessed. The results obtained in the MTXG were compared to those of the RMTXG, RSTG and control groups. All data are presented as gene expression values, unless otherwise indicated.

\section{Biochemical Analysis}

Preparing the Samples

A sample of $25 \mathrm{mg}$ of tissue was homogenized using a solution of $1.15 \% \mathrm{KCl}$ (Merck, Darmstadt, Germany). The homogenates were centrifuged at $4,000 \mathrm{rpm}$ for $30 \mathrm{~min}$ at $4^{\circ} \mathrm{C}$ and the supernatants were separated by decantation for the measurement of GSHPx and MDA.

Another $25 \mathrm{mg}$ of tissue was washed with isotonic sodium chloride $(\mathrm{NaCl}$; IE Ulagay) for tGSH analysis. First, the $\mathrm{NaCl}$ was removed from the samples, then the final volume was brought up to $2 \mathrm{ml}$ by adding a phosphate buffer solution [0.213 $\mathrm{g}$ of $\mathrm{NaH}_{2} \mathrm{PO}_{4} \cdot 2 \mathrm{H}_{2} \mathrm{O}, 1.563 \mathrm{~g}$ of $\mathrm{Na}_{2} \mathrm{HPO}_{4} \cdot 2 \mathrm{H}_{2} \mathrm{O}$ (Merck), $0.038 \mathrm{~g}$ of EDTA (Sigma-Aldrich) in $100 \mathrm{ml}$ of distilled water at $\mathrm{pH}$ 7.4].

The tissues were homogenized in an icy environment and centrifuged at 1,000 rpm for $15 \mathrm{~min}$ at a temperature of $4^{\circ} \mathrm{C}$. The supernatants were separated and used for the measurement of protein concentration according to the method described by Bradford [13].

\section{MDA Analysis}

The MDA levels were determined spectrophotometrically at $532 \mathrm{~nm}$ according to the method described by Ohkawa et al. [14]. This method is based on spectrophotometric measurement of absorbance of the pink-colored complex which is formed by thiobarbituric acid and $\mathrm{MDA}$ at a high temperature $\left(95^{\circ} \mathrm{C}\right)$. The $0.1 \mathrm{ml}$ of supernatant separated for the measurement of GSH-Px and MDA was added to a solution containing $0.1 \mathrm{ml}$ of $8.1 \%$ sodium dodecyl sulfate, $1.5 \mathrm{ml}$ of $20 \%$ acetic acid (Merck), $1.5 \mathrm{ml}$ of $0.9 \%$ thiobarbituric acid (Sigma-Aldrich) and $0.3 \mathrm{ml}$ of $\mathrm{dH}_{2} \mathrm{O}$. The mixture was incubated at $95^{\circ} \mathrm{C}$ for $1 \mathrm{~h}$. Upon cooling, $5 \mathrm{ml}$ of $\mathrm{n}$-butanol:pyridine (v/v, 15:1; Merck) was added. The mixture was vortexed for $1 \mathrm{~min}$ and centrifuged for $30 \mathrm{~min}$ at 4,000 rpm. The absorbances of the $0.15-\mathrm{ml}$ final solutions were measured by spectrophotometry at $532 \mathrm{~nm}$. The standard curve was obtained by using 1,1,3,3-tetramethoxypropane (Sigma-Aldrich).

tGSH Analysis

tGSH analysis was measured according to the method described by Sedlak and Lindsay [15]. In this method, sulfhydryl 
groups of GSH form a yellow-color TNB (5-thio-2-nitrobenzoic acid) following a chemical reaction with DTNB $\left(5,5^{\prime}\right.$-dithiobis [2-nitrobenzoic acid]). The intensity of this color is measured spectrophotometrically at $412 \mathrm{~nm}$.

For measurement, a cocktail solution $(5.85 \mathrm{ml} 100 \mathrm{mM} \mathrm{Na}-$ phosphate buffer, $2.8 \mathrm{ml} 1 \mathrm{mM}$ DTNB, $3.75 \mathrm{ml} 1 \mathrm{mM} \mathrm{NADPH}$ and $80 \mu \mathrm{l} 625 \mathrm{U} / \mathrm{l}$ glutathione reductase; Sigma-Aldrich) was prepared. Before measurement, $0.1 \mathrm{ml}$ of meta-phosphoric acid (Sigma-Aldrich) was added to $0.1 \mathrm{ml}$ of homogenate to precipitate the proteins, followed by centrifugation at 2,000 rpm for $2 \mathrm{~min}$ to remove the precipitated proteins. After this, the $0.15-\mathrm{ml}$ cocktail solution was added to the $50 \mu \mathrm{l}$ of supernatants described above. The results were compared with the standard curves obtained by using GSSG (Sigma-Aldrich).

\section{GSH-Px Analysis}

The measurement of GSH-Px activity was made according to the method of Lawrence and Burk [16] using the supernatant obtained after tissue homogenization. To each $25-\mu$ l supernatant solution, $125 \mu \mathrm{l}$ of phosphate buffer solution $\left(0.988 \mathrm{~g} \mathrm{Na}_{2} \mathrm{HPO}_{4}\right.$, $0.379 \mathrm{~g} \mathrm{KH}_{2} \mathrm{PO}_{4}, 0.062 \mathrm{~g}$ EDTA, $0.011 \mathrm{~g} \mathrm{NaN}_{3}$ in $100 \mathrm{ml}$ of distilled water at $\mathrm{pH} 7.4), 50 \mu \mathrm{l}$ of cosubstrate mixture (0.004 g NADPH, $0.008 \mathrm{~g} \mathrm{GSH}$ ) and $50 \mu \mathrm{l}$ of glutathione reductase (in $5 \mathrm{ml}$ of distilled water) were added. This was followed by adding $25 \mu \mathrm{l}$ of hydrogen peroxide to the mixture. Finally, the reduction in absorbances was recorded spectrophotometrically in $5 \mathrm{~min}$.

\section{Gene Expression of IL-1 $\beta, T N F-\alpha$ and $M P O$}

RNA Isolation

RNA was isolated from the homogenized ileum tissue samples using the Roche Magna Pure Compact LC device (Roche, Mannheim, Germany) with MagNA Pure LC RNA Kit (Roche). The quantity and quality of the isolated RNA was assessed with a nucleic acid measurement device (Maestro, Nano). The 50- $\mu$ l RNA samples were stored at $-80^{\circ} \mathrm{C}$.

\section{cDNA Synthesis}

cDNA was synthesized from the isolated RNA samples using the Transcriptor First Strand cDNA Synthesis Kit (Roche). For each subject, $1 \mu \mathrm{l}$ of $\mathrm{ddH}_{2} \mathrm{O}, 10 \mu \mathrm{l}$ of RNA and $2 \mu \mathrm{l}$ of random primer were combined and incubated in a thermal cycler for 10 min at $65^{\circ} \mathrm{C}$. After incubation, $4 \mu \mathrm{l}$ of reaction buffer, $0.5 \mu \mathrm{l}$ of RNAase, $2 \mu$ l of deoxynucleotide mix and $0.5 \mu$ lof reverse transcriptase were added. The reactions were incubated for $10 \mathrm{~min}$ at $25^{\circ} \mathrm{C}, 30 \mathrm{~min}$ at $55^{\circ} \mathrm{C}$ and $5 \mathrm{~min}$ at $85^{\circ} \mathrm{C}$, and then held at $4^{\circ} \mathrm{C}$.

Quantitative Gene Expression Evaluation by Real-Time

Polymerase Chain Reaction

For each cDNA sample, gene expression of IL- $1 \beta$, TNF- $\alpha$, MPO and the reference gene (G6PD) was analyzed using the Roche LightCycler 480 II Real-Time PCR instrument. PCRs were recorded in a final volume of $20 \mu \mathrm{l}: 5 \mu \mathrm{l}$ of cDNA, $3 \mu \mathrm{l}$ of distilled water, $10 \mu \mathrm{l}$ of LightCycler 480 Probes Master (Roche) and 2- $\mu \mathrm{l}$ primer-probe set (Real-Time Ready single assay, Roche). The cycle conditions of the relative quantitative PCR were preincubation at $95^{\circ} \mathrm{C}$ for $10 \mathrm{~min}$ followed by 45 amplification cycles of $95^{\circ} \mathrm{C}$ for $10 \mathrm{~s}, 6^{\circ} \mathrm{C}$ for $30 \mathrm{~s}, 72^{\circ} \mathrm{C}$ for $1 \mathrm{~s}$, followed by cooling at $40^{\circ} \mathrm{C}$ for $30 \mathrm{~s}$. The quantitative PCR analysis and calculation of quantification cycle $(\mathrm{Cq})$ values for relative quantification were performed with LightCycler 480 software, version 1.5 (Roche). Relative quan- titative amounts were calculated by dividing the target genes by the expression level of the reference gene. The reference gene was used for the normalization of target gene expression.

\section{Histopathological Study}

The ileal tissues taken from the rats were fixed in $10 \%$ formalin for $24 \mathrm{~h}$. Following the routine procedures, $4-\mu \mathrm{m}$ sections obtained from paraffin blocks were stained with hematoxylin and eosin. The stained sections were evaluated with a light microscope (BX 52, Olympus, Tokyo, Japan) by a pathologist who did not know the applied treatment protocol.

\section{Statistical Analysis}

Statistical analyses were performed using the Statistical Package for Social Sciences for Windows version 18.0 (SPSS, Chicago, Ill., USA). Descriptive statistics for each variable were determined. The normality of the data distribution was assessed with the Kolmogorov-Smirnov test. The results for continuous variables were recorded as the mean \pm standard deviation (SD). The significance of differences between the groups was determined using a oneway ANOVA test followed by Fisher's post hoc LSD (least significant differences) analysis. A p value $<0.05$ was considered significant.

\section{Results}

\section{Biochemical Results}

The MDA level was significantly higher $(\mathrm{p}<0.001)$ in the group that received MTX $(8.33 \pm 2.5 \mu \mathrm{mol} / \mathrm{g}$ protein $)$ than that of the RMTXG, RSTG and control groups $(3.45$ $\pm 0.71,2.07 \pm 0.16$ and $2.9 \pm 0.44 \mu \mathrm{mol} / \mathrm{g}$ protein, respectively). There was no statistically significant difference between the RMTXG, RSTG and control groups regarding the MDA levels ( $p>0.05)$. Also, MDA levels were lower in the RSTG $(2.07 \pm 0.16 \mu \mathrm{mol} / \mathrm{g}$ protein $)$ than in both the RMTXG and control groups (3.45 \pm 0.71 and 2.9 $\pm 0.44 \mu \mathrm{mol} / \mathrm{g}$ protein; table 1$)$.

The tGSH level in the MTXG $(0.97 \pm 0.29 \mathrm{nmol} / \mathrm{g}$ protein) was significantly lower than the levels in the RMTXG, RSTG and control groups (4.58 \pm 0.75, $5.8 \pm$ 0.18 and $5.23 \pm 0.7 \mathrm{nmol} / \mathrm{g}$ protein, $\mathrm{p}<0.001$, respectively; table 1). The GSH-Px level in the MTXG (5.22 \pm 0.35 $\mathrm{U} / \mathrm{g}$ protein) was significantly lower than the levels in the RMTXG, RSTG and control groups $(10.25 \pm 1.33,17.67$ \pm 1.51 and $12.17 \pm 1.83 \mathrm{U} / g$ protein, $\mathrm{p}<0.001$, respectively; table 1). The highest tGSH and GSH-Px levels were obtained in the RSTG. Thus, RST inhibited the tGSH and GSH-Px decreases induced by MTX.

\section{Gene Expression Results}

The IL-1 $\beta$ level in the MTXG (40.33 \pm 5.43$)$ was significantly higher than in the RMTXG, RSTG and control groups $(16.17 \pm 3.71,8.22 \pm 0.38$ and $11.33 \pm 2.07$, respec- 
Fig. 1. Sections of the ileum tissue of MTXG (a, b), RMTXG (c, d) and RSTG (e). a Widespread necrosis, severe PNL infiltration and marked inflammation were observed in the mucosa (thin arrow). The same findings were found in the submucosa (thick arrow). b Villus epithelial damage in the mucosa (thin arrow) and crypt necrosis (thick arrow) were observed. d The RMTXG showed only mixed inflammatory cell infiltration of mild severity. f Histopathological examination of the ileum tissue of the control group. HE. Original magnification. a-d $\times 100$. e, $\mathbf{f} \times 40$.

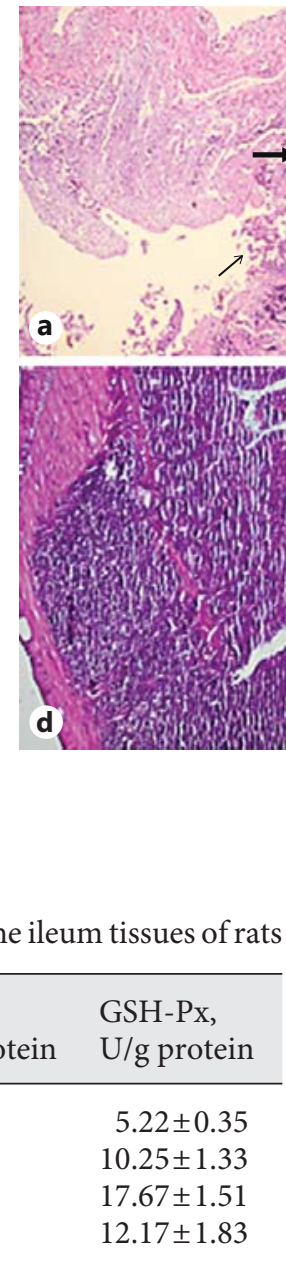

Table 1. MDA, tGSH and GSH-Px levels in the ileum tissues of rats

\begin{tabular}{lllr}
\hline Group & $\begin{array}{l}\text { MDA, } \\
\mu \mathrm{mol} / \mathrm{g} \text { protein }\end{array}$ & $\begin{array}{l}\text { tGSH, } \\
\mathrm{nmol} / \mathrm{g} \text { protein }\end{array}$ & $\begin{array}{l}\text { GSH-Px, } \\
\mathrm{U} / \mathrm{g} \text { protein }\end{array}$ \\
\hline MTXG & $8.33 \pm 2.5$ & $0.97 \pm 0.29$ & $5.22 \pm 0.35$ \\
RMTXG & $3.45 \pm 0.71$ & $4.58 \pm 0.75$ & $10.25 \pm 1.33$ \\
RSTG & $2.07 \pm 0.16$ & $5.8 \pm 0.18$ & $17.67 \pm 1.51$ \\
Control & $2.9 \pm 0.44$ & $5.23 \pm 0.7$ & $12.17 \pm 1.83$ \\
\hline
\end{tabular}

Values are means \pm SD.
Table 2. IL-1 $\beta$, TNF- $\alpha$ and MPO gene expression levels in the ileum tissues of rats

\begin{tabular}{lrll}
\hline Group & IL-1 $\beta$ & TNF- $\alpha$ & \multicolumn{1}{l}{ MPO } \\
\hline MTXG & $40.33 \pm 5.43$ & $6.08 \pm 0.59$ & $9 \pm 1.41$ \\
RMTXG & $16.17 \pm 3.71$ & $2.23 \pm 0.53$ & $4.18 \pm 0.35$ \\
RSTG & $8.22 \pm 0.38$ & $1.55 \pm 0.19$ & $1.95 \pm 0.1$ \\
Control & $11.33 \pm 2.07$ & $2.15 \pm 0.33$ & $3.43 \pm 0.48$ \\
\hline
\end{tabular}

Values are means \pm SD. tively, $\mathrm{p}<0.001$; table 2). The TNF- $\alpha$ level in the MTXG $(6.08 \pm 0.59)$ was significantly higher than in the RMTXG, RSTG and control groups $(2.23 \pm 0.53,1.55 \pm 0.19$ and $2.15 \pm 0.33$, respectively, $\mathrm{p}<0.001$; table 2$)$. The MPO gene expression level in the MTXG $(9 \pm 1.41)$ was higher than the levels in the RMTXG, RSTG and control groups $(4.18 \pm 0.35,1.95 \pm 0.1$ and $3.43 \pm 0.48$, respectively, $\mathrm{p}<$ 0.001 ; table 2).

Oral MTX enhanced IL- $1 \beta$, TNF- $\alpha$ and MPO gene expression in rat ileum tissue. On the other hand, RST inhibited the increase in IL- $1 \beta$, TNF- $\alpha$ and MPO gene expression induced by MTX $(\mathrm{p}<0.001)$. RST also suppressed IL- $1 \beta$, TNF- $\alpha$ and MPO gene expression in the healthy tissue. The IL- $1 \beta$, TNF- $\alpha$ and MPO gene expression in the RMTXG, RSTG and control groups was significantly lower than that in the MTXG $(\mathrm{p}<0.001$; table 2$)$.

\section{Histopathological Results}

In the ileal mucosa of the MTXG (fig. 1a; indicated by the thin arrow), widespread necrosis, severe polymorphonuclear leukocyte (PNL) infiltration, mixed inflammatory cell infiltration and marked inflammation were observed. The same findings were found in the submucosa, indicated by the bold arrow in figure la. Additionally, in the MTXG, villus epithelial damage in the mucosa (thin arrow) and crypt necrosis (thick arrow) were observed (fig. 1b). No necrosis was observed in the RMTXG which received RST. The normal superficial villus epithelium and crypt epithelial cells of the RMTXG are shown in figure 1c. The RMTXG showed only mixed inflammatory cell infiltration of mild severity (fig. 1d). The normal histopathology in the full-thickness sections of the RSTG and control groups are shown in figure $1 \mathrm{e}$ and $\mathrm{f}$. 


\section{Discussion}

Our study confirmed the oxidative stress caused by MTX administration in the rat ileum. Oxidative stress is essentially an imbalance between oxidants and antioxidants [17]. In vivo, MDA acts as an oxidant, while GSH reacts as an antioxidant. It has been reported that while MDA is increased, GSH is decreased in oxidative tissue damage $[17,18]$. In agreement with previous reports [19, 20 ], our study showed that the MDA level was higher and tGSH and GSH-Px levels were lower in the ileal tissues of rats given MTX compared to controls. Our results showed decreased MDA levels but increased tGSH and GSH-Px levels in the ileum tissue of rats treated with RST compared to the MTXG. These findings also confirmed the results of Sener et al. [21]. The oxidative tissue injury caused by MTX could be inhibited by antioxidant molecules through the inhibition of the production of free radicals before damage occurs and even during the already formed oxidative damage $[21,22]$.

In addition, MTX significantly increased the IL- $1 \beta$, TNF- $\alpha$ and MPO gene expression in the ileum tissue of rats in the MTXG. These findings support the study of Alamir et al. [7] who reported that MTX induced IL-1 $\beta$ and TNF- $\alpha$ gene expression in the tissue of the small intestine. In another study, it is claimed that IL- $1 \beta$, TNF- $\alpha$ and other cytokines can induce not only local but also systemic tissue damage [23]. IL-1 $\beta$ plays a major role in the inflammatory cascade by causing apoptosis and leukocyte infiltration [24]. The role of cytokines and particularly of TNF- $\alpha$ in intestinal inflammation has been implicated [25].

TNF- $\alpha$, besides its cytotoxic effect, plays a major role in the regulation of inflammatory reactions and inflammation [26]. TNF- $\alpha$ and IL- $1 \beta$ appear in the early phase of inflammation and over similar signal molecules that lead to an oxidative burst of neutrophils and release of free radicals $[24,26]$.
The PNL activation causes the excessive production of MPO. Therefore, MPO is recognized as a precursor of neutrophil release in tissue damage [27]. It was also reported that MTX significantly increased MPO activity, which was the indicator of the inflammatory response in the small intestine and stomach tissue [28].

The gene expression and biochemical results of this study were fully consistent with the histopathological results. Severe PNL and mixed inflammatory cell infiltration and inflammation were observed in the ileum samples of the MTXG, where we found high values of MDA, IL- $1 \beta$ and TNF- $\alpha$, but low values of tGSH and GSH-Px. In this study, in the intestinal tissue of rats in the MTXG, we also observed necrosis in the epithelium of mucosa, submucosa, villi and crypts. It has been reported that MTX causes damage in the crypts and villi of the small intestinal mucosa [29]. It has also been claimed that MTX-induced damage in the small intestinal mucosa is related to reactive oxygen species, IL- $1 \beta$, TNF- $\alpha$ and MPO $[28,30]$. As far as we know, there is no study in the literature on the protective effect of RST against small intestinal toxicity induced by MTX. However, RST inhibits the MTX-induced increased production of cytokines and oxidants, as well as the decreased production of antioxidants [30]. In our study, RST decreased the oxidant parameters in healthy tissue, increased the antioxidant parameters and also inhibited IL- $1 \beta$, TNF- $\alpha$ and MPO gene expression.

\section{Conclusion}

In this study, the biochemical and histopathological tests and gene expression analysis revealed that MTX caused marked damage in the ileum tissue but RST inhibited MTX-induced ileal damage.

\section{References}

1 Lagarce L, Zenut M, Laine-Cessac P: Methotrexate pharmacology (in French). J Gynecol Obstet Biol Reprod (Paris) 2015;44:203-211.

2 Mohamed HJ, Sorich MJ, Kowalski SM, et al: The role and utility of measuring red blood cell methotrexate polyglutamate concentrations in inflammatory arthropathies - a systematic review. Eur J Clin Pharmacol 2015;71: 411-423.

The Impact of RST in Rat Ileum Tissue
3 Wang $\mathrm{H}$, Brook CL, Whittaker AL, et al: Effects of Streptococcus thermophilus $\mathrm{TH}-4$ in a rat model of doxorubicin-induced mucositis. Scand J Gastroenterol 2013;48:959-968.

-4 van Ede AE, Laan RF, Rood MJ, et al: Effect of folic or folinic acid supplementation on the toxicity and efficacy of methotrexate in rheumatoid arthritis: a forty-eight week, multicenter, randomized, double-blind, placebocontrolled study. Arthritis Rheum 2001;44: 1515-1524.
5 Demiryilmaz I, Uzkeser H, Cetin N, et al: Effect of mirtazapine on gastric oxidative stress and DNA injury created with methotrexate in rats. Asian J Chem 2013;25:2047-2050.

-6 Niscola P, Romani C, Cupelli L, et al: Mucositis in patients with hematologic malignancies: an overview. Haematologica 2007;92: 222-231. 
7 Alamir I, Boukhettala N, Aziz M, et al: Beneficial effects of cathepsin inhibition to prevent chemotherapy-induced intestinal mucositis. Clin Exp Immunol 2010;162:298-305.

$\checkmark 8$ Leitao RF, Brito GA, Oria RB, et al: Role of inducible nitric oxide synthase pathway on methotrexate-induced intestinal mucositis in rodents. BMC Gastroenterol 2011;11:90.

-9 Kaynar L, Cetin A, Hacioglu SK, et al: Efficacy of royal jelly on methotrexate-induced systemic oxidative stress and damage to small intestine in rats. Afr J Tradit Complement Altern Med 2012;9:412-417.

10 Bavaresco L Vezzull Q: Stilbene phytoalexins physiology of grapevine (Vitis spp.) as affected by viticultural factors; in Govil JN Singh, VK, Arunachala C (eds): Recent Progress in Medicinal Plants: Drug Development from Molecules. Houston, Studium Press, 2006, vol 11 , pp 389-410.

11 Chuang CC, Martinez K, Xie G, et al: Quercetin is equally or more effective than resveratrol in attenuating tumor necrosis factor- $\alpha$ mediated inflammation and insulin resistance in primary human adipocytes. Am J Clin Nutr 2010;92:1511-1521.

12 Abdali D, Samson SE, Grover AK: How effective are antioxidant supplements in obesity and diabetes? Med Princ Pract 2015;24:201215.

13 Bradford MM: A rapid and sensitive method for the quantitation of microgram quantities of protein utilizing the principle of proteindye binding. Anal Biochem 1976;72:248-254.
14 Ohkawa H, Ohishi N, Yagi K: Assay for lipid peroxides in animal tissues by thiobarbituric acid reaction. Anal Biochem 1979;95:351358.

15 Sedlak J, Lindsay RH: Estimation of total, protein-bound, and nonprotein sulfhydryl groups in tissue with Ellman's reagent. Anal Biochem 1968;25:192-205.

16 Lawrence RA, Burk RF: Glutathione peroxidase activity in selenium-deficient rat liver. Biochem Biophys Res Commun 1976;71: 952-958.

17 Kisaoglu A, Borekci B, Yapca OE, et al: Tissue damage and oxidant/antioxidant balance. Eurasian J Med 2013;45:47-49.

18 Al-Qabandi W, Owayed AF, Dhaunsi GS: Cellular oxidative stress and peroxisomal enzyme activities in pediatric liver transplant patients. Med Princ Pract 2012;21:264-270.

19 Duman DG, Kumral ZNÖ, Ercan F, et al: Saccharomyces boulardii ameliorates clarithromycin-and methotrexate-induced intestinal and hepatic injury in rats. Br J Nutr 2013;110: 493-499.

20 Moghadam AR, Mohajeri D, Namvaran-Abbas-Abad A, et al: Protective effect of turmeric extract on ethotrexate-induced intestinal damage and oxidative stress. Chin J Nat Med 2013;11:477-483.

21 Sener G, Eksioglu-Demiralp E, Cetiner M, et al: $\beta$-Glucan ameliorates methotrexate-induced oxidative organ injury via its antioxidant and immunomodulatory effects. Eur J Pharmacol 2006;542:170-178.
22 Sorg O: Oxidative stress: a theoretical model or a biological reality? CR Biol 2004;327:649662.

23 Grace PA: Ischaemia-reperfusion injury. Br J Surg 1994;81:637-647.

24 Dinarello CA: Proinflammatory cytokines. Chest 2000;118:503-508.

-25 Sandborn WJ, Hanauer SB: Antitumor necrosis factor therapy for inflammatory bowel disease: a review of agents, pharmacology, clinical results, and safety. Inflamm Bowel Dis 1999;5:119-133.

26 Semenzato G: Tumour necrosis factor: a cytokine with multiple biological activities. $\mathrm{Br} \mathrm{J}$ Cancer 1990;61:354-361.

27 Konaka A, Kato S, Tanaka A, et al: Roles of enterobacteria, nitric oxide and neutrophil in pathogenesis of indomethacin-induced small intestinal lesions in rats. Pharmacol Res 1999; 40:517-524.

28 Jahovic N, Sener G, Cevik H, et al: Amelioration of methotrexate-induced enteritis by melatonin in rats. Cell Biochem Funct 2004. 22:169-178.

29 Acipayam C, Bayram I, Daglioglu K, et al: The protective effect of hesperidin on methotrexate-induced intestinal epithelial damage in rats: an experimental study. Med Princ Pract 2014;23:45-52.

30 Yulug E, Turedi S, Alver A, et al: Effects of resveratrol on methotrexate-induced testicular damage in rats. ScientificWorldJournal 2013;2013:489659. 